\title{
Polysèmes
}

Revue d'études intertextuelles et intermédiales

15 | 2016

L'or et l'art

\section{Gold in Wright of Derby's Paintings}

L'or dans la peinture de Wright of Derby

\section{Muriel Adrien}

\section{(2) OpenEdition \\ Journals}

Electronic version

URL: http://journals.openedition.org/polysemes/940

DOI: 10.4000/polysemes.940

ISSN: 2496-4212

\section{Publisher}

SAIT

\section{Electronic reference}

Muriel Adrien, « Gold in Wright of Derby's Paintings », Polysèmes [Online], 15 | 2016, Online since 15 May 2016, connection on 19 April 2019. URL : http://journals.openedition.org/polysemes/940 ; DOI : 10.4000/polysemes. 940

This text was automatically generated on 19 April 2019

Polysèmes 


\title{
Gold in Wright of Derby's Paintings
}

\author{
L'or dans la peinture de Wright of Derby
}

\author{
Muriel Adrien
}

1 Wright of Derby ${ }^{1}$ (1734-1797) lived during the second half of the $18^{\text {th }}$ century, at a time of transition between a prescientific age and the age of Enlightenment, with its new faith in modern science and progress. Wright's perception and use of gold reflects the changes that his times were negotiating, and his paintings divert former uses of this chemical element to convey modern and personal conceptions. Wright of Derby did depict former beliefs about all things golden, such as in The Alchemist, whose dark arts were supposed to transform base metals into gold, that elusive philosopher's stone. Moreover, his many representations of volcanoes and geochemical phenomena evoke all sorts of subterranean, secretive, telluric and obscure paths meant to lead to the discovery of gold, mainly concentrated in the Earth's core. Even if some of his paintings show he was acquainted with alchemy, these pictures are counterpoised with his depictions of modern themes: scientific experiments as well as the Industrial Revolution. In his blacksmith's workshops and forges, the central element that is afire is molten metal: iron. More so even than gold, iron had become a highly valuable metal as it accounted for the development of the Industrial Revolution, and therefore Great Britain's leading position and prestige. We will see how through a secret pictorial device, Wright of Derby eventually transmutes gold into iron, celebrates workmanship and brings up in filigree the idea of a new profane transcendence.

The intimate crisscross of former benighted times and the age of Enlightenment is transcribed pictorially in the chiaroscuro of Wright of Derby's paintings, enhanced by the glimmering effects of the Carlo Maratta frames. Through a cryptic contrivance relating the scene to the frames, gold acquires metapictorial value: shrouded in darkness, just like light itself, it cannot be seen, but it is what allows visibility to surface. We will see how Wright of Derby capitalized on former symbolic uses of gold to showcase the new values of his time and his own ultimate artistic quest. 


\section{Alchemical rites}

3 Wright of Derby depicted scenes evoking the lust for gold that predated modern science, such as in The Alchemist or the Air Pump where the dove recalls the birds contained in the retorts of the allegories of alchemical transmutations. Many of these experiments are redolent of mysterious cabalistic texts and freemason rites. The social circle of Wright was freemason, whether it be the intellectuals of the Lunar Society ${ }^{2}$ or some of his patrons. ${ }^{3}$ The indoor scenes seem to take place in a gothic or occult atmosphere steeped in ceremonious and almost esoteric or necromantic solemnity, with architectural features reminiscent of pagan temples. ${ }^{4}$

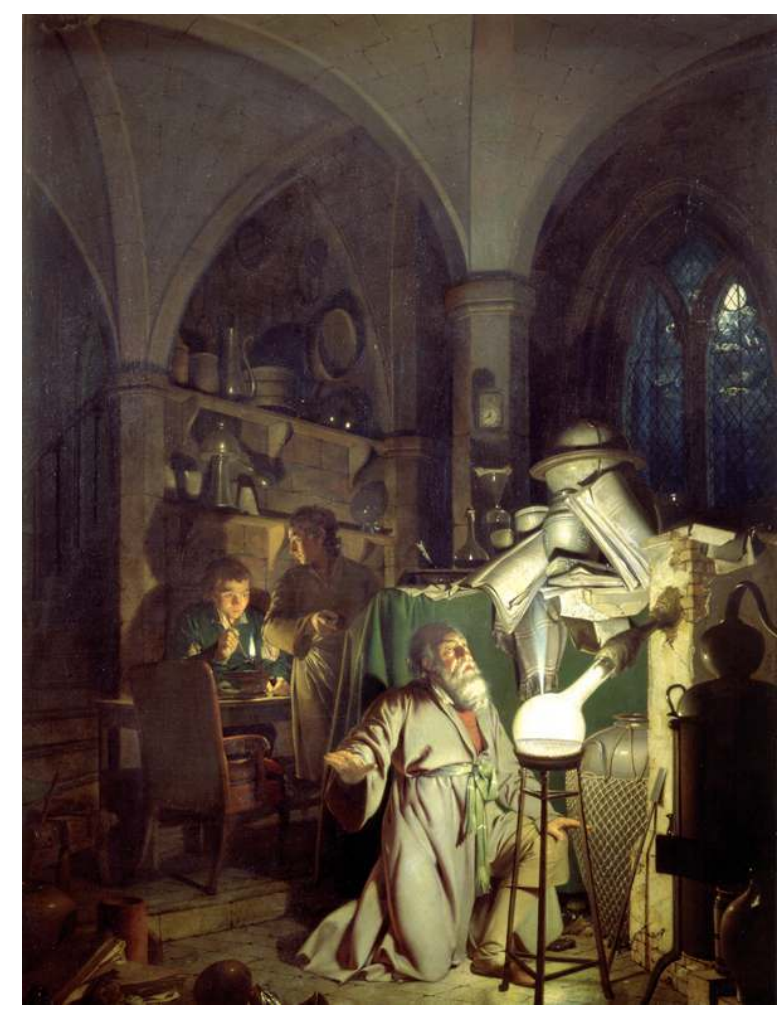

Joseph Wright of Derby, The Alchymist in Search of the Philosophers' Stone discovers Phosphorus and prays for the successful conclusion of his operation as was the custom of the Ancient Chymical Philosophers (1771), oil on canvas, 127×102cm, Derby Museum and Art Gallery, UK, Creative Commons 


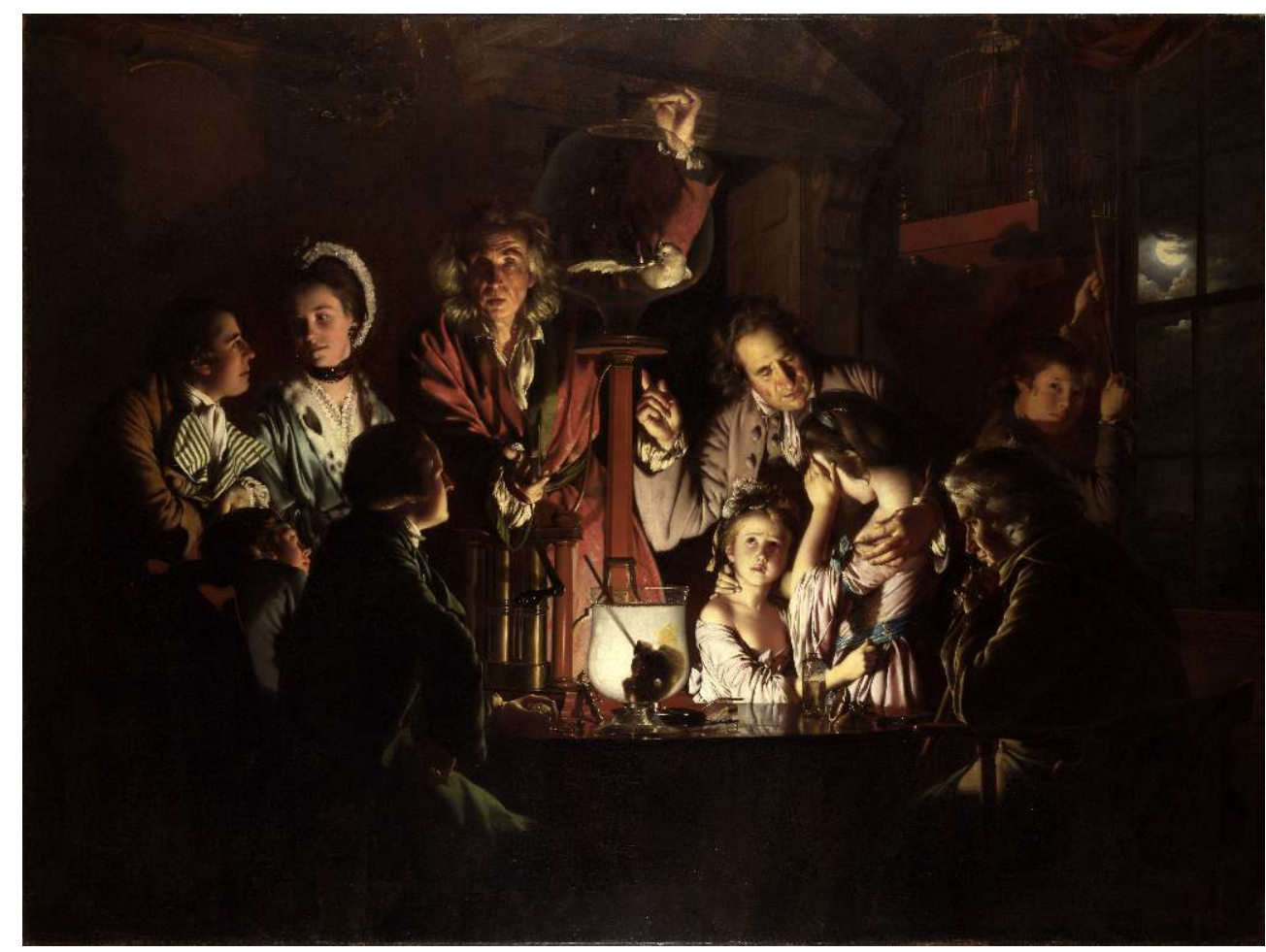

Joseph Wright of Derby, An Experiment on a Bird in an Air Pump (1768), oil on canvas, 182,9x243.9cm, The National Gallery, London, Creative Commons

4 The alchemist's moon is omnipresent in Wright's oeuvre, with its silvery hues as counterpoints to the tawny and gilded artificial lights. Moonlight is a well-known symbol of witchcraft, an artificial host, a wan and pallid haloed disc in the depths of night, like the golden star of a shepherd become industrial. Moreover, Wright of Derby's flamboyant depictions of geochemical phenomena seem to probe the subterranean core of the Earth in which the intoxicating gold is churned. The dark primitive underground world accessed in outlandish terrestrial grottoes or grottoes by the seaside, ${ }^{5}$ are claustrophobic spaces echoed by the air pump, the tomb of Miravan and shrines that may hold treasures such as the golden alchemical teeth of the dragon of Cadmus's myth that Wright of Derby illustrated.

5 Further cavities in the shape of glorious erupting volcanoes spurt out fire and incandescent lava, red-hot scoriae and ignite blazing haloes. But there is no real sense of urgency and danger, and Wright seems to be recording blast furnaces hurling russet, bronze and gold upwards from their heart. After a trip to Italy of a year and a half, Wright had done no less than thirty versions of the Vesuvius eruption. ${ }^{6}$ Three versions of the Girandola were painted as matching pieces, and the two enthralling phenomena were frequently compared by observers like Sir William Hamilton. ${ }^{7}$ The igneous telluric light finds its pendant in atmospheric pyrotechnics, ${ }^{8}$ both of which conjure up the alluring lustre of gold on a wondrous scale against the night. From grottoes to gushing volcanoes to pulsating fireworks, earthly matter and man-made golden light challenge the darkness, in a visual performance bonding earth and sky, encoding the transition between a divine and a terrestrial light, this red-hot crucible enacting alchemical dreams on a grand scale. 


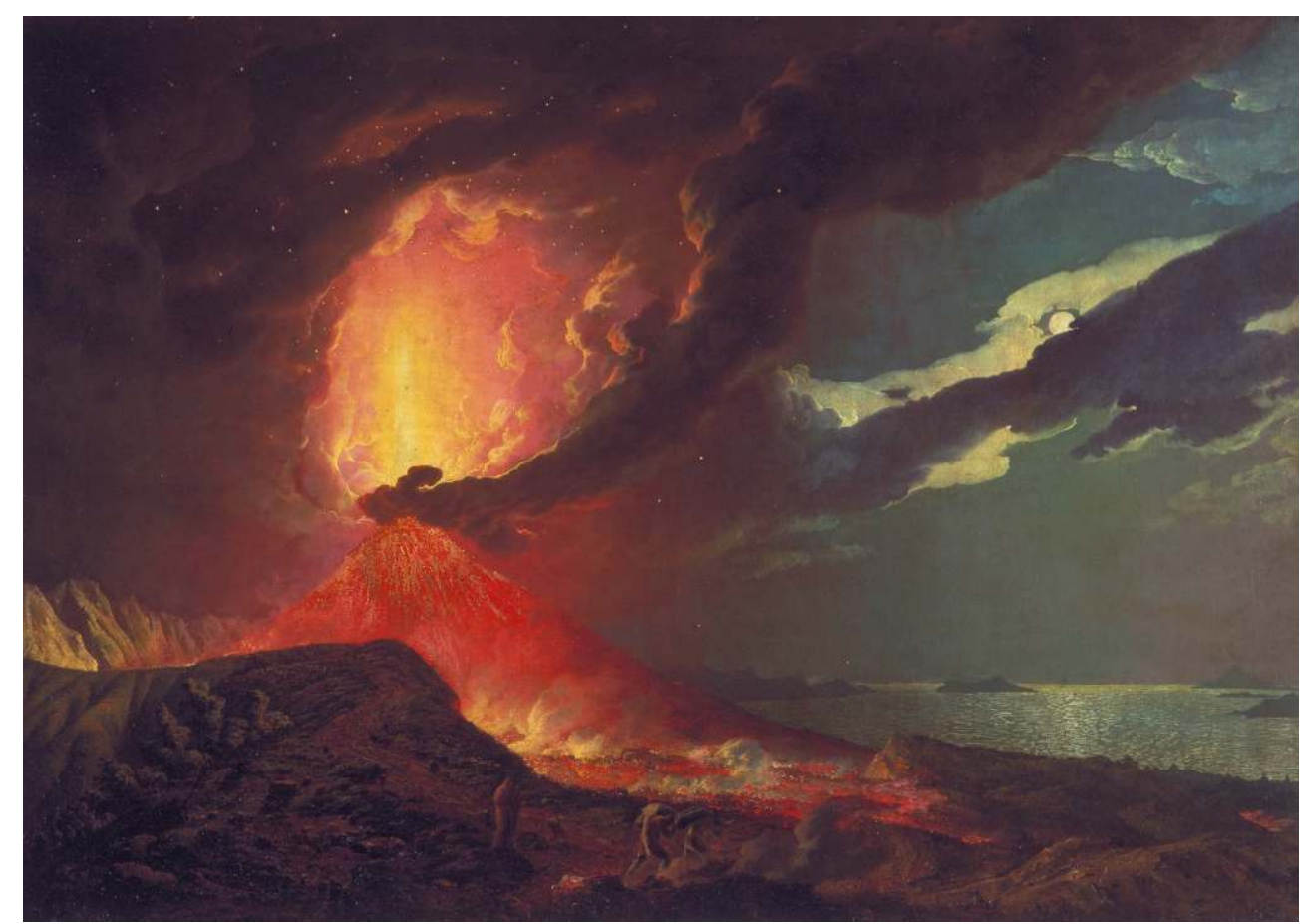

Joseph Wright of Derby, Vesuvius in Eruption, with a View over the Islands in the Bay of Naples (c. 1776), huile sur toile, $122 \times 1764 \mathrm{~cm}$, Tate Britain, Creative Commons

\section{Celebrating man's labor}

However, there is no denying that Wright of Derby's main body of work focuses on modern positivist themes, and extols technological innovations, scientific experiments as well as the Industrial Revolution, such as the modern lighting setting ablaze Arkwright's cotton-mill in the early 1780 s. ${ }^{9}$

In the years between 1771 and 1773, Wright completed and exhibited no fewer than five paintings on the theme of a blacksmith's shop or a forge, unveiling a marked and sustained interest in this subject matter. In the Yale Blacksmith's Workshop (the one with the beam), three men are crafting an iron horse-shoe. Wright has imagined that a traveler has broken down on a journey and the farrier is therefore working outside by the light of a candle. The central element that is afire, the white-hot piece of iron, has an unusually bright glow. What is the secret behind the blinding white-hot iron bar? Investigations in the 1990s gave it away: beneath the image of the conspicuous ingot, a piece of gold leaf was inserted between a thick layer of lead-white and an opaque layer of Naples yellow. ${ }^{10}$ Gold is transmuted into iron, contrary to the alchemical process. Why is Wright of Derby burying a secret treasure under this iron bar-why does he insert and deposit a precious ore to depict something so lumpen, so trivial as iron, in so humble a subject-matter-the labour of a common blacksmith, the forging of a horse-shoe? This puzzling decision deserves an explanation. 


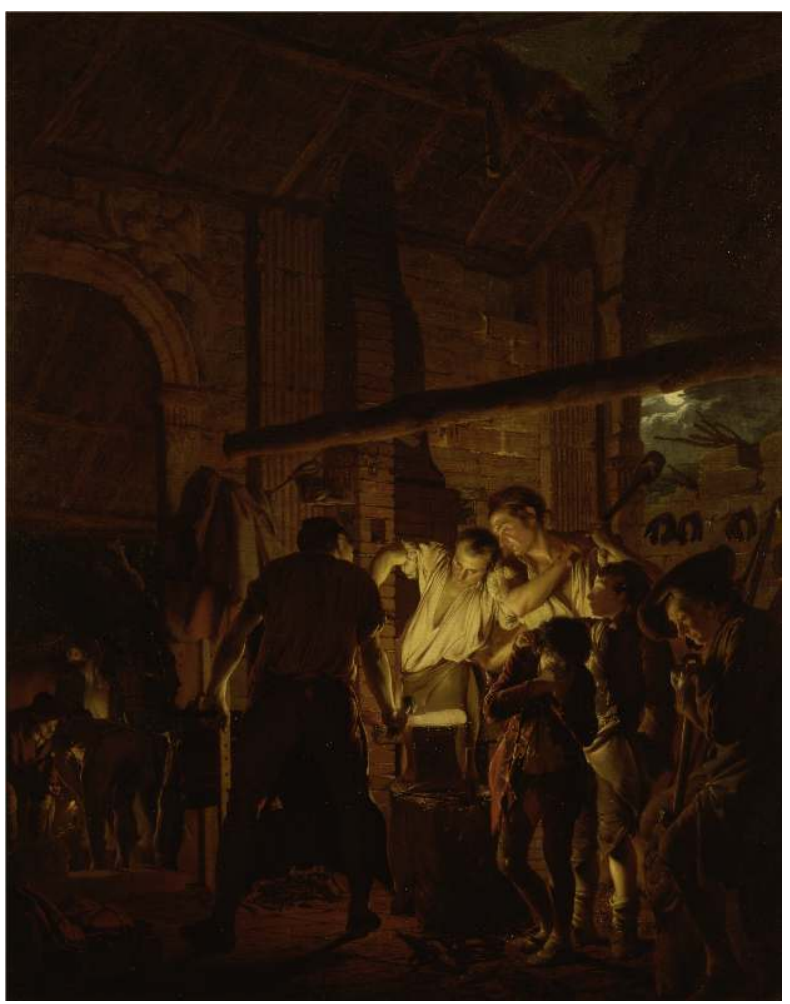

The Blacksmith's Workshop (1771), oil on canvas, $128.3 \times 104 \mathrm{~cm}$, Yale Center for British Art, Paul Mellon Collection

In this depiction of the aftermath of a road accident, value is given to the generous service brought to people in need of help outside opening hours. The picture highlights the utility and benefits of the labor of blacksmiths, at once practical and essential. And when efficiently fulfilling basic human needs, their actions are haloed with lofty social and moral purpose as well as economic value. Wright confers to the scene a solemn and dramatic dignity which was quite unusual for such a subject matter. As manual laborers, blacksmiths were considered as commonplace or "low" characters, of the kind the $17^{\text {th }}$ century Netherlandish School was keen on depicting. ${ }^{11}$ But Wright's workers, far from being vulgar, lowbred, uncouth or ludicrous, are exalted as full-length noble figures bent over their tasks, silhouetted against the light; they are shown from a slight low-angle point of view which magnifies them, the shadows and walls acting as extensions of their erect postures, legs apart in front of the furnace, where a new energy is being created. Although their job is in no way exceptional, their posture and graceful power is endowed with the majesty of traditional heroes or demigods, with muscular strength and highlighted features far more handsome than Vulcan, the god of fire, who would have featured in a mythological painting. The carved angel above the arcade of a derelict church is also a topos of religious painting, which elevates this otherwise humble genre scene, investing it with the aura of a painting of the Grand Manner. These healthy, virile, concentrated men are working for the prosperity of a country turned towards progress and the future.

9 As Great Britain's economic power was fast developing, industriousness came to be seen as crucial to the nation's progress and improvement. In his Second Treatise of Government (first published in 1690), John Locke extolled labor, saying "Man [was] a fabricator, homo faber, created by God, deus faber, in his own image". He upheld that labor generated 
economic value much more so than land or money, and moreover contributed to producing civilization. This was taken up later by Adam Smith who, against bullionism, argued for productive skillful and useful labor which secured "the wealth of nations". Hume, in his Moral Essays of 1745, claimed that industry enabled men to fight away the melancholy that goes with indolence. ${ }^{12}$ Industry went hand in hand with experimentation and technical prowess, in which Wright engages here as well, trying his hand at this new pictorial medium.

In his Essay Concerning Human Understanding (1689), which was acclaimed throughout the $18^{\text {th }}$ century, Locke stated that exploiting the uses of iron was a precondition for the prosperity and refinement of societies. In this perspective, iron attained a higher status than gold itself. Using the precious and decorative ore that is gold to enhance iron is a way to glorify a material that is much more common and drab but of far more practical value. Of course, the auriferous brightness magnifies the iron metal. ${ }^{13}$

11 This piece of metal responding so well to light sparks visions of a nativity scene in one of the forge pictures, ${ }^{14}$ with the child Jesus in the manger. ${ }^{15}$ This new icon or miracle of the Enlightenment, iron, thereby somewhat takes on His divine symbolic charge. The gold leaf also harkens back to the golden age of religious painting, the International Gothic, which endowed divine characters with haloes made of gold. As a matter of fact, the night scenes of Wright of Derby that celebrate scientific popularization or praise the Industrial Revolution are fraught with figurative conventions of the sacred night piece. For example, in the Blacksmith's Workshop of Yale, the scene, with its cross-like composition in some deconsecrated abbey, smacks of a Flagellation. ${ }^{16}$ Allusions to canonical religious scenes are secularized and subverted to glorify a new profane transcendence-the light of knowledge, reason and scientific progress ${ }^{17}$ - since this new man-made ore is wrought by blacksmiths, wrought by the power of man.

\section{Metapictorial message}

The forging of iron may also be a comment by Wright on his artistic practice and identity. Wright wanted to put himself at a safe distance from the high manner of the recently founded Royal Academy, which anyway excluded him from membership. ${ }^{18} \mathrm{He}$ felt greater affinities with the Society of Artists of Great Britain, which preferred more local, particularized and naturalistic renderings of modern subjects, a far cry from the continental manner much vaunted by Reynolds.

Away from the intellectual notion of the liberal artist promoted by the Royal Academy, Wright assumed the posture of an industrious craftsman, whose skillful picture-making had moral, economic, and social purposes. As David Solkin says, Wright was himself, as a painter, "a metalworker: lead is the main component of lead white, for instance, while Naples yellow contains cadmium, iron, and titanium" (189). His poet friend Hayley compared the pouring of the volcano with Wright's colors flowing on his canvas. ${ }^{19}$ Wright may have been trying to conform to the definition of his own name: Samuel Johnson's Dictionary of 1755 defines "wright" as a "workman; an artificer; a maker; a manufacturer". The fact that Wright concealed his technique was in line with the craftsman trade policies of closely guarded secrets. In the picture, the light is hidden behind the communicative medium, i.e. the wright-ing paper. 

Enlightenment age. This chiaroscuro is prolonged and enhanced by the opulent gilded brightness and deep shades of the hollows of the Carlo Maratta frames. ${ }^{21}$ Gold which had been the material of the International Gothic progressively had moved to the outer boundaries of the picture, i.e. the frame, as the linear perspective gained ground. $\mathrm{P}$ robably made to sparkle by the candlelight, the flickering reflectiveness of the frame interplays exquisitely with the luminosity or golden hues of the scene, drawing the spectator toward and into the picture. ${ }^{22}$ The broad and hollow mouldings or scotias reinforce the perspective; they act as showcases to the scene which is also staged by chiaroscuro. what is shrouded in the shade and what surfaces in light, for which gold is a hidden source of visibility. Gold therefore acquires a metapictorial value: just like light itself, it cannot be seen, but it is what allows visibility and radiance. Just like the moon reflecting the sunlight, the gold sheet reflects light through the coats of paint, and interacts with the ambient darkness.

There is one other dark painting in which Wright slipped a thin strip of gold leaf. In that painting, the black colour of the metal parts of the lamp conceals a silver and gold sheet, applied onto the layer of the red-brown underpainting. ${ }^{23}$ This painting is revealingly called the Academy by Lamplight-academy meaning the school but also a painting exercise. ${ }^{24}$ The youth bears an expression as enraptured in front of the sculpture-i.e. a work of art-, as the youth in front of manual labour in the Yale Blacksmith's Workshop.

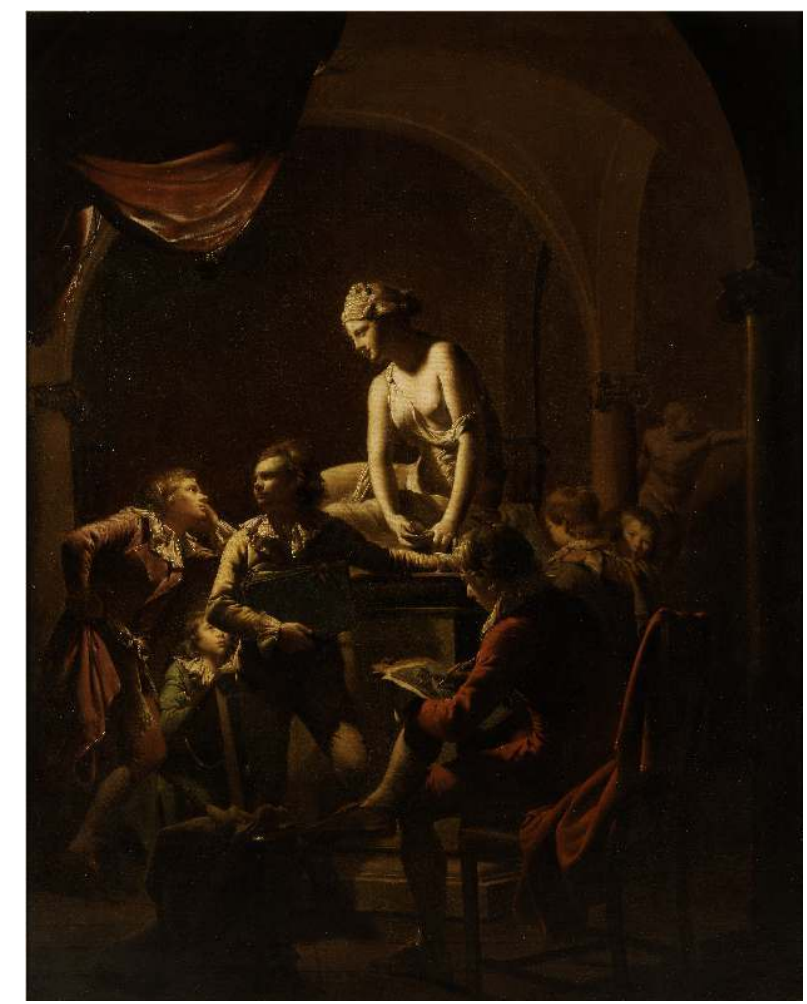

Joseph Wright of Derby, Academy by Lamplight (1769), oil on canvas, 127x101cm, Yale Center for British Art, Creative Commons

In the picture he exhibited in 1771 alongside the Yale Blacksmith, what the alchemist chances upon is actually not the philosopher's stone, but the discovery of phosphorus. ${ }^{25}$ 
This alchemist is not gazing at the sky or at a volcano spewing forth, but is staring at the bluish gleam of the phosphorus jet which escapes from his apparatus, therefore at a kind of mundane man-made light that glows in the dark. ${ }^{26} \mathrm{He}$ has found a way to change matter into light, just as Wright produces luminosity from the raw pigments. And like God, too, the artist keeps most of his creative inspiration out of sight, ${ }^{27}$ leaving us bedazzled. You may try and scratch the surface of a painting to plumb its illusionistic depth, truth is all you shall find is dust. The pendant of The Alchemyst was the Hermit contemplating a heap of bones. ${ }^{28}$ The missing link between both is probably Miravan Opening the Tomb of his Ancestors. ${ }^{29}$ Miravan was a young nobleman who read an inscribed tablet which said: "In this tomb is a greater treasure than even Croesus possessed". He broke open the beguiling cavity, only to find nothing but dust and ashes from the decomposing corpses, and certainly no buried treasure. An inscription said: "Here dwells repose. Sacrilegious wretch, searchest thou for gold among the dead! Go, son of avarice, Thou cannot enjoy repose" (Lock 544-545). The underlying metapictorial message is that it is tempting to think the illusionism of pictures goes beyond their flatness, but all one can find is the dust of metal pigments and the depth of the artist's work. If Wright underlays iron with gold and therefore paradoxically twists the problem the other way around, turning it on its head via a reductio ad absurdum argument, it is to bring into the open the merits of craftsmanship in painting. Wright painted the death of Pliny in the great eruption of Vesuvius in $79 \mathrm{AD}$, but also his famous legend ${ }^{30}$ of the origin of painting (Natural History, book XXXV, 14). ${ }^{31}$ The young lover of the woman is about to vanish-to be gone-, and all she will be left with is his shadow she will outline and the clay out of which her potter father will make his profile in the kiln fire on the "right". Similarly, the golden rule of the allure of a good picture is nothing but a labor of love and craftsmanship and then the blessed eternal repose of the surface, its object being gone. 
The idol of gold cannot outshine the discreet art of labor, not least the sublime labor of art here, literally sublimated by the light of gold.

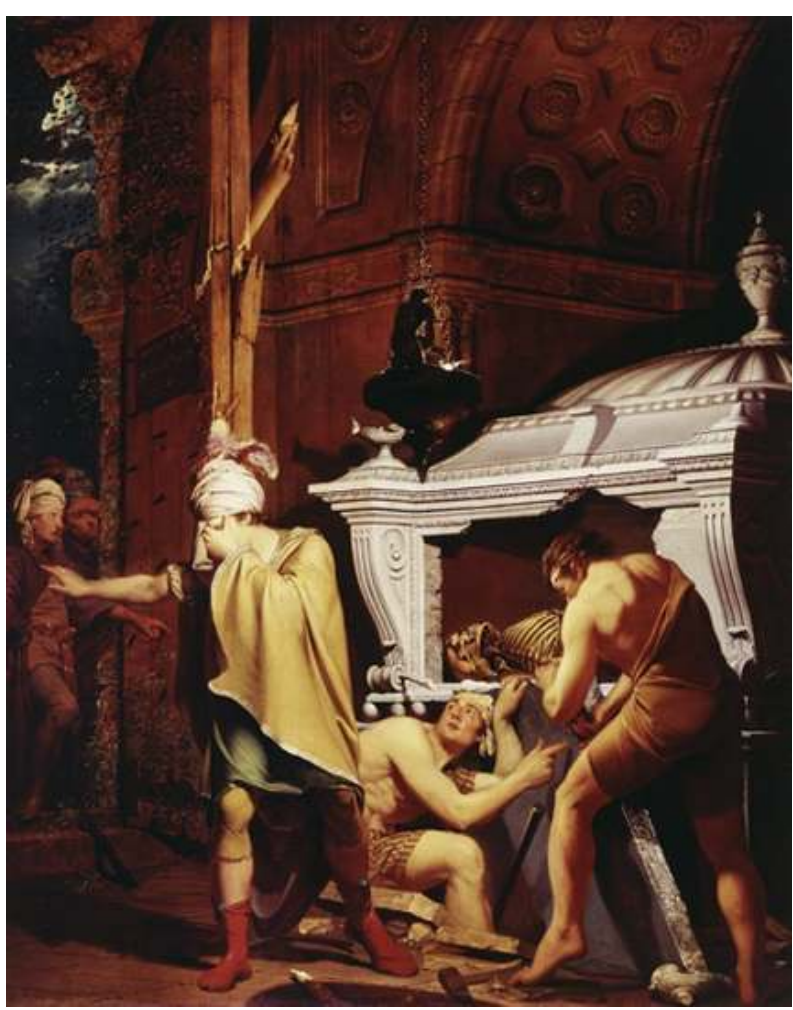

Joseph Wright of Derby, Miravan Breaking Open the Tomb of his Ancestors (1772), oil on canvas, $127 \times 101.6 \mathrm{~cm}$, Derby Museum and Art Gallery, Creative Commons

18 Gold used to flaunt the ostentatious and opulent power of religion; but the lack of depth of the ore and its reflectiveness sends back to the viewer mere seductive bedazzlement, in the case of Byzantine icons for example. In the case of Wright of Derby, gold partakes of a secretive purpose meant to give depth, potency and perspective to his artistic endeavors and prospects. Instead of being foregrounded in its splendor and fascination, gold is subdued in a statement about unobtrusive, penetrating and low-key application. In the somewhat Protestant fashion Max Weber associated with the Industrial Revolution, Wright soberly keeps his treasure and design out of view, undisclosed and unexposed, plays down the value of his well-wrought pictures, only to manifest the enchantment of his industriousness and craftsmanship. In so doing, he appropriates the golden leaf and makes his picture his own private cryptic geological quarry, where the buried vein was to be tapped and discovered some two hundred years later by scholars striking it lucky. All in all, Wright's paintings absorbed and subverted the former symbolic uses of gold so as to highlight-in the shadows - the chiaroscuro and values of the times and the artist's own Holy Grail, his wright artistic quest. 


\section{BIBLIOGRAPHY}

Daniels, Stephen. Joseph Wright. London: Tate Gallery Publishing, 1999.

Egerton, Judy. Wright of Derby. London: Tate Gallery Publishing, 1990.

Fraser, David. “'Fields of Radiance': The Scientific and Industrial Scenes of Joseph Wright". The Iconography of Landscape. Denis Cosgrove and Stephen Daniels (eds). Cambridge: CUP, 1989, 277-312.

Garo, Isabelle. L'Or des images - art, monnaie, capital. Montreuil: Éditions la ville brûle, 2013.

Lock, Frederick Peter. “Wright of Derby's Miravan Breaking Open the Tomb of His Ancestors". The Burlington Magazine 141.1158 (Sept. 1999): 544-545.

Nicolson, Benedict. Joseph Wright of Derby. 2 vols. The Paul Mellon Foundation for British Art, London: Routledge and Kegan Paul; New York: Pantheon Books, 1968.

Robinson, Eric. “Joseph Wright of Derby: The Philosophers' Painter". The Burlington Magazine 100.663 (June 1958): 214-215.

Solkin, David H. “Joseph Wright of Derby and the Sublime Art of Labor". Representations 83.1

(Summer 2003): 167-194.

Wallis, Jane. Joseph Wright of Derby, 1734-1797. Derby: Derby Museum and Art Gallery, 1997.

\section{NOTES}

1. The phrase "of Derby" was added to distinguish him from the Liverpool artist Richard Wright.

2. Among those he knew who were freemasons: John Whitehurst lived on the same side of the street as him. Erasmus Darwin became Wright's doctor and friend; Wright depicted him with a quill pen when he had just finished The Botanic Garden. Darwin and Priestley upheld that alchemy was a progressive, materialistic religion, much less benighted than the times' religiosity. Gisborne and Wedgwood were also friends. See Stephen Daniels, Joseph Wright, London: Tate Gallery Publishing, 1999, 29.

3. Such as Catherine the Great, or Earl Ferrers, elected Fellow of the Royal Society for his observations on the movements of Venus, and Grand Master of the English freemasons of the Lodge of Strict Observance in 1762-64.

4. A temple with arched galleries and ionic columns surrounds an ancient nymph in the Academy by Lamplight, a temple is topped with a pediment in the Air Pump. A mad scientist presides over what could be interpreted as a seance, in front of the entrance of the Holy of Holies. The scene smacks of necromancy, or sadism. A great priest of sorts, violently lit up from below, with a white mane and a wild hypnotic look in his eyes, has the power of life and death over a bird trapped in an air pump.

5. Grottoes by the seaside depicted by Wright include at least three in the Gulf of Salerno.

6. He actually had not managed to view it in Naples. In The Eruption of Vesuvius, with a View over the Islands in the Bay of Naples, next to a greenish gleaming sea and moon, a cone of incandescent lava projects fire radiating in a blazing halo, which acts as a vertical projection of the horizontal oval of the crater, thereby establishing an equivalence between the telluric world and the 
atmospheric world. As Wright climbed Mount Vesuvius he mentioned his old geologist friend John Whitehurst to his brother: "When you see Whitehurst, tell him I wished for his company when on Mount Vesuvius his thoughts would have centered in the bowels of the mountain, mine skimmed over the surface only". Jane Wallis, Joseph Wright of Derby, 1734-1797, Derby: Derby Museum and Art Gallery, 1997, 14. Whitehurst's treatise suggests the existence of a vast subterranean sea of fire beneath the Earth's surface, occasionally bursting here and there into volcanoes.

7. Hamilton drew parallels between both: "it is impossible to describe the beautiful appearance of these Girandolas of red hot stones far surpassing the most astonishing fire-work" (Benedict Nicolson, Joseph Wright of Derby, 2 vols., The Paul Mellon Foundation for British Art, London: Routledge and Kegan Paul, New York: Pantheon Books, 1968, 80).

8. The art of pyrotechnics, imported from Italy and influenced by Baroque theatre, appealed to all Europeans in the $18^{\text {th }}$ century. The fireworks displays launched from the Castel Sant'Angelo in Rome were a major tourist attraction. The Annual Girandola draws its name from a revolving wheel on the roof of the Castel Sant'Angelo where the firework rockets were launched. See also at least nine Cottages on fire, as well as Fire at a Villa seen by Moonlight, probably in the Roman Campania.

9. See Arkwright's Cotton Mills by Night (c.1782-83), oil on canvas, $99.7 \times 125.7 \mathrm{~cm}$, private collection. 10. The layer-structure of the iron bar is as follows: on top of the dead coloring is applied thick lead white, on which is laid a gold leaf, which in its turn is completely covered by an opaque layer of Naples yellow paint. Rica Jones in Judy Egerton, Wright of Derby, London: Tate Gallery Publishing, 1990, 177. This technique was not used more than twice. It should be noted that Naples yellow is a traditional pigment appropriate to the rendering of light, texture and substance because it can offer several shades of brightness ranging from impasto to glazing.

11. Such as Smith's Forge then believed to be by the Haarlem painter Adriaen Brouwer which must have inspired Wright, be it via James Macardell's mezzotint.

12. In eighteenth-century Britain, even if it was thought that economic progress went hand in hand with greater refinement, it was also feared that too great a prosperity was likely to induce self-satisfaction, complacency in a people ready to rest on its laurels, a fate which had befallen Roman empires to which Britain was often compared. This type of cyclical process resonated with Wright's bipolar condition, i.e. feverish energy alternating with periods of lethargy.

13. For these last two paragraphs, see Solkin.

14. An Iron Forge (1772), oil on canvas, $121.9 \times 132.1 \mathrm{~cm}$, Lord Romsey, Broadlands Collection.

15. Although it highlights a magnified pre-victorian pater familias, and not the Christian Mother in her glory.

16. Other references borrowed from religious paintings: the children of the Orrery recall putti. According to Nicolson, the Gladiator evokes the Christ in Emmaüs by Volmarijn. In the Air Pump, the mad scientist who looks like some hypnotizing wizard has his index raised like that of God giving life to Adam in the Creation of Michelangelo, the air pump acting as a central cross on the experimental altar. The Alchemist combines Saint Francis receiving the stigmata, Saint Jerome in prayer or other transfixed saints. The face of the protagonist is elated, transfigured by the phosphorescent light. The moon itself resembles a host.

17. If religious allusions are secularized, it may rather be to draw light into the human realm, confer human qualities to it, and even start giving its authorship to man. What emits light in the demonstration scenes or the forges is not the traditional sacred character or memento mori, but the object of the scientific experiment or industrial scene. Even in Wright's night scenes that do not involve science or industry, artifacts-i.e. objects invented by man-emanate light. If for some, natural phenomena and the explanation of its causes testified above all to the power, the beauty and the order of divine creation, for others, the instruments of experimental philosophy proved the importance of science and showed man using the forces of nature as he willed. In 
Wright's paintings, the Christian God seems rather outshined by man's desire for knowledge and by his ambition to decipher the rational structures and mechanisms of the universe.

18. Wright exhibited at the Academy every year from 1778 to 1782, and was elected as an ARA or an associate in 1781. In 1783, after an argument with the Royal Academy about the poor positions of his paintings with the hanging committee, he was defeated in the election for full academician status.

19. "But see far off the modest Wright retire!

Alone he rules his Element of fire;

Like meteors darting through the gloom of the night

His sparkles flash upon the dazzled sight

Our eyes with momentary anguish smart

And nature trembles at the power of art.

May thy bold colour claiming endless praise,

For ages shine with undiminish'd blaze,

And when the fierce Vesuvio burns no more,

May his red deluge down his canvas pour!" [My emphasis] (Hayley quoted by Benedict Nicolson, Joseph Wright of Derby, 2 vols., The Paul Mellon Foundation for British Art, London: Routledge and Kegan Paul; New York: Pantheon Books, 1968, 142)

20. The chiaroscuro connects Wright patently with past "golden makers" such as Gerrit van Honthorst or Rembrandt van Rijn.

21. See the frames of Girl Reading a Letter (c.1767-70), oil on canvas, $76 \times 61 \mathrm{~cm}$, Two Young Boys Fighting over a Bladder (c.1767-70), oil on canvas, 91.5x71.2cm, Young Woman Reading a Letter by Candlelight (c.1760-66), oil on canvas, $76 \times 61 \mathrm{~cm}$.

22. For more information on Wright's frames, see Paul Mitchell, "Wright's Picture Frames", in Judy Egerton, Wright of Derby, London: Tate Gallery Publishing, 1990, 181-196.

23. Rica Jones explored the samples of cross-sections of the layers of paint. Judy Egerton, Wright of Derby, London: Tate Gallery Publishing, 1990, 268.

24. This hidden source of light is associated with infatuation. The light is of utmost importance, and no wonder: those who hold the power of light can create composition and space, and thus invent realities. And men are thereby vested with new and extraordinary powers.

25. Wright called this work The Alchymist, in Search of the Philosopher's Stone, Discovers Phosphorus, and prays for the successful Conclusion of his operation, as was the custom of the Ancient Chymical Astrologers. Phosphorus was first discovered in 1676, and stimulated the research of Robert Boyle (1627-91). Influenced by Thomas Wyck (or Teniers), Wright also drew from Macquer's account of manufacturing phosphorus, as well as Burdett's personal advice.

26. Esotericism is replaced by rational considerations, or rather a certain mundane atmosphere. If a certain baroque theatricality underlies the painting, the scene is rather of Flemish inspiration if one looks at the precise and humdrum description of a profusion of banal and runof-the-mill objects.

27. Often we do not see the source of light in Wright's depicted scenes: light issues from behind in the Gladiator and the Orrery. It is never foregrounded, but merely reflected by the objects next to it and the enraptured faces.

28. In The Hermit Studying Anatomy, in a grotto, against a backdrop which includes a mini-Styx, the hermit muses over the passing of time and life's transience: when its wick is spent, the lamp will be extinguished.

29. Deluded by a false fancy, overcome by greed, he broke open the tomb, only to discover the treasure which he has now forfeited was the eternal repose that follows a good life. The original source of the story is elusive. Wright copied his literary source in his Account Book. Story from an Eastern tale? In fact, his source is probably from a volume entitled Letters concerning Taste (1755) by John Gilbert Cooper. The hanging lamp is turning its back to tend the low light over the 
tomb. See also Indian Widow: a Funeral Pyre. Life is given to painting by light and inert matter, fire and ashes.

30. The Young Corinthian (1783-84), oil on canvas, $106.3 \times 130.9 \mathrm{~cm}$, National Gallery of Art, Washington DC. The Neoclassical profiles are flattened as on a low relief or as on a canvas. The silhouette of the lover is actually inspired by an antique low relief that Wright had sketched in Rome. The Corinthian maid is sometimes called Dibutades, from her father's name. During neoclassicism (c.1770-1820), this legend inspired John Hamilton Mortimer, Alexander Runciman and David Allan (Origin of Painting). Wright wrote to Hayley: "I have painted my picture from your idea". (Judy Egerton, Wright of Derby, London: Tate Gallery Publishing, 1990, 134). He painted this picture for Wedgwood, hence the potter's oven, with, as a companion picture, that of Penelope.

31. The daughter of the potter Butades de Sicyon, Dibutades, was in love with a young man. Since this young man was going abroad, she came up with the idea of outlining the shadow of his face projected onto the wall by the light of a lantern; her father applied clay to the outline and hardened it in fire. Pliny links this legend to the art of modelling, and the drawing capacity of shadows to the origin of painting. The Corinthian maid was moved by love to invent the art of portraiture. Inspired by an eroticizing shadow, the aim of the drawing is to act as a mnemonic aid, a makeshift, a substitute of the absent loved one. This propitiatory drawing retains the presence of the loved one to a certain extent, warding off death, especially if it remains vertical: here lays not he. By fixing him forever, by making him unreal, the girl paradoxically immortalizes his image. Light and shadow via a love story were the makings of art.

\section{ABSTRACTS}

Wright of Derby (1734-1797) lived at a time of transition between a former world of protosciences and the Enlightenment period, with its new faith in science and progress. This article purports to explore how, in this context, his paintings relate to gold: the way he envisaged gold reflects the changing nature of value at the time and conveys his personal conception about art.

Wright of Derby did depict former beliefs about all things golden, such as in The Alchemist, whose dark arts were meant to transform base metals into gold. Moreover, his representations of volcanoes and geochemical phenomena conjure up all sorts of subterranean, secretive, telluric and obscure paths meant to lead to the discovery of gold, mainly concentrated in the Earth's core. Even if some of Wright of Derby's paintings show he was acquainted with alchemy, he later turned to the depiction of modern themes: scientific experiments as well as the Industrial Revolution. In his blacksmith's workshops and forges, the central element that is afire is molten metal: iron. Interestingly, the secret behind the exceedingly bright glow of this piece of metal is the sheet of gold between the lead white and the Naples yellow. Gold is finally being transmuted into iron, magnified by the auriferous brightness. More so even than gold, iron had become a highly valuable metal as it accounted for the development of the Industrial Revolution, and therefore Great Britain's leading position and prestige. This new element is wrought by blacksmiths, wrought by the power of man, rather than by God or underground forces. In the subtext of Wright of Derby's scenes, replete with religious reminiscences, is the idea of a new profane transcendence.

The intimate crisscross of former times thought of as steeped in benightedness and the Enlightenment is transcribed pictorially in the chiaroscuro of Wright of Derby's paintings, and further enhanced by the glimmering effects of the Carlo Maratta frames, which interact with the 
represented scene itself. As frames, they designate what is to be seen, which is precisely this connection between what is shrouded in the shade and what surfaces in light, for which gold is a hidden source of visibility. Gold therefore acquires a metapictorial value: just like light itself, it cannot be seen, but it is what allows visibility. This article therefore studies how Wright of Derby capitalized on former symbolic uses of gold to showcase the new values of his time and his own ultimate artistic quest.

Wright of Derby (1734-1797) vivait à une époque de transition entre l'époque des protosciences et celle des Lumières avec sa nouvelle foi dans la science et le progrès. Cet article étudie, dans ce contexte, la portée symbolique de son utilisation de l'or dans ses peintures. La façon dont il envisage cet élément chimique reflète la nature changeante de la notion de valeur à l'époque et la manière dont il conçoit son art. Wright en détourne les usages anciens au profit d'une sécularisation de la lumière et d'une valorisation du travail de l'artisan qui s'initie aux mystères de l'univers et à leur représentation artistique.

Certaines peintures de Wright of Derby représentent des scènes qui véhiculent d'anciennes croyances sur l'or, comme L'Alchimiste. En outre, ses représentations de volcans, de topoi telluriques ou autres phénomènes géochimiques évoquent toutes sortes de chemins souterrains, secrets et occultes destinés à découvrir l'or concentré dans le noyau de la Terre. Wright of Derby se tourna aussi vers des thèmes plus modernes: les expériences scientifiques ainsi que la Révolution Industrielle. Dans ses ateliers et forges, le secret de l'aveuglante blancheur de la barre de fer travaillée à chaud, de cette pièce de métal en fusion, est la feuille d'or glissée entre le blanc de plomb et le jaune de Naples. À l'inverse de l'alchimie, l'or est enfin transmué en fer, ainsi consacré par la brillance aurifère. Il s'agit donc de vanter le fer, ce matériau que travaille la main de l'homme, emblème smithien de la Révolution Industrielle et de la richesse anglaise. Les réminiscences religieuses des tableaux qui mettent en scène le fer font apparaître en filigrane l'idée d'une nouvelle transcendance profane.

Le chassé-croisé intime de l'obscurantisme et des Lumières est transcrit graphiquement dans le clair-obscur des peintures de Wright of Derby. Ce clair-obscur est mis en valeur par les effets scintillants des cadres Carlo Maratta qui interagissent avec la scène représentée. Comme les cadres, il désigne ce qui doit être vu, qui est précisément ce lien entre ce qui est tapi dans l'ombre et ce qui émerge à la lumière, pour laquelle l'or est une source cachée de visibilité. L'or acquiert ainsi une valeur métapicturale : tout comme la lumière elle-même, il ne peut pas être vu, mais il est ce qui permet la visibilité. Ainsi, cet article verra comment Wright of Derby exploite les usages symboliques de l'or pour mettre en exergue les nouvelles valeurs de son temps et sa propre quête artistique.

\section{INDEX}

Mots-clés: peinture britannique, or, fer, forgeron, alchimie, Lumières, clair-obscur Keywords: British painting, gold, iron, blacksmith, alchemy, Enlightenment, chiaroscuro oeuvrecitee Alchemist (The), Experiment on a Bird in the Air Pump (An), Tomb of Miravan (The), Eruption of Vesuvius (The), Arkwright's Cotton Mills by Night, Blacksmith's Workshop (The), Iron Forge (An), Academy by Lamplight 


\section{AUTHORS}

MURIEL ADRIEN

Muriel Adrien is currently a senior lecturer at the English Department of Toulouse University, France, where she teaches courses in visual studies and British painting mainly. Her main area of research is late $18^{\text {th }}$ - and early $19^{\text {th }}$-century British painting, as well as photography. She is chief editor of the peer-reviewed online journal on the English-speaking world, Miranda. 